\title{
PERBANDINGAN MEKANISME SERTIFIKASI PRODUK HALAL ANTARA INDONESIA DENGAN MALAYSIA
}

Tubagus Yudi Muhtadi ${ }^{1}$

1Ilmu Pemerintahan -

FISIP Universitas Islam

Syekh-Yusuf

tubagusyudi1969@unis.ac.i

$\underline{\mathrm{d}}$

\begin{abstract}
ABSTRAK
Penelitian ini dimaksudkan untuk menggambarkanmekanisme pelaksanaan sertifikasi produk halal yang dilaksanakan oleh dua negara, yaitu Indonesia dan Malaysia.Pelaksanaan sertifikasi produk halal di Indonesia diselenggarakan oleh Badan penyelenggara Jaminan Produk Halal (BPJPH)yang sebelumnya dilaksanakan oleh LPPOM MUI (Majelis Ulama Indonesia) yang berawal dari gerakan masyarakat yang didukung negara. Tujuan utamanya adalah melindungi umat islam dari barang-barang haram. Sedangkan di Malaysia dilaksanakan oleh JAKIM (Jabatan Kemajuan Islam Malaysia). Terdapat perbedaan yang mendasar pelaksanaan sertifikasi halal yang dilaksanakan oleh kedua lembaga di dua negara berbeda ini, walaupun memiliki tujuan yang sama, yakni memberikan keamanan dan kepastian halal kepada masyarakat muslim di kedua negara tersebut dalam mengkonsumsi produk makanan dan minimunnya. Kajian ini menggunakan metode studi pustaka dengan memanfaatkan beragam literatur yang membantu menjelaskan permasalahan yang menjadi fokus kajian. Hasil kajian menerangkan bahwa proses perjalanan pelaksanaan sertifikasi halal baik di Indonesia maupun di Malaysia memiliki kemiripan, dimana semula sertifikasi dilaksanakan oleh bukan lembaga pemerintah kemudian diambil alih oleh lembaga pemerintah. Adapun yang membedakan adalah uji laboratorium dimana di Indonesia dilakukan oleh LPPOM MUI sedangkan di Malaysia dilaksanakan oleh laboratorium independen yang sudah terakreditasi.
\end{abstract}

Kata kunci: Sertifikasi Halal, Agama, dan negara.

\section{A. PENDAHULUAN}

Indonesia adalah negara Islam dengan penduduk muslim terbesar di dunia, sekitar $86 \%$ penduduk Indonesia adalah muslim, maka hukum asal makanan di Indonesia adalah halal. Mudzhar (1998 : 12-13) menjelaskan bahwa persoalan produk halal pernah menjadi polemik di Indonesia. Selama ini sertifikasi halal ditentukan oleh MUI dengan memberikan fatwa terhadap produsen yang menginginkan produknya diaudit, melalui uji coba laboratorium LPPOM MUI (Lembaga Pengkajian Pangan, Obatobatan dan Kosmetika).

Indonesia adalah negara Islam dengan penduduk muslim terbesar di dunia, sekitar $86 \%$ penduduk Indonesia adalah muslim, maka hukum asal makanan di Indonesia adalah halal. Persoalan produk halal pernah menjadi polemik di Indonesia. 


\section{PELITA}

Selama ini sertifikasi halal ditentukan oleh MUI dengan memberikan fatwa terhadap produsen yang menginginkan produknya diaudit, melalui uji coba laboratorium LPPOM MUI (Lembaga Pengkajian Pangan, Obat-obatan dan Kosmetika) untuk direkomendasikan ke Badan penyelenggara Jaminan Produk Halal (BPJPH).

Perlindungan konsumen terhadap makanan yang halal selama ini dilakukan oleh MUI, dimana pada tahun 1989 mendirikan LPPOM-MUI, 1991 untuk mengkoordinasikan pembinaan dan pengawasan produksi makanan olahan sebagai tindak lanjut sertifikasi halal, maka lahirlah Keputusan PresidenNomor 23 Tahun 1991 tentang Kesehatan yang dikoordinasikan oleh Menko Kesra bersama MUI. Baru pada tahun 1992 melalui Undang-Undang Nomor 23 Tahun 1992 tentang Kesehatan, maka masalah makanan halal mulai mendapat tempat.

Berdasarkan peraturan tersebut Menteri Kesehatan berwenang melakukan pengawasan terhadap makanan halal baik dari segi kesehatan maupun dari segi kehalalalnya. Pada tahun 1996 pengawasan makanan halal kembali dipertegas dengan lahirnya UU Nomor 7 tahun 1996 tentang pangan, secara tegas menyatakan baik produk luar (impor) maupun dalam negeri harus berlabel halal. Untuk pelaksanaan labelisasi halal operasionalnya kemudian di atur dalam Keputusan Menteri Kesehatan RI nomor 83/Menkes/SK/VII/1996 tentang pencantuman label halal pada makanan. Surat Keputusan ini kemudian diperbaharui dengan Surat Keputusan Menteri Kesehatan Nomor 924/Menkes/SK/VIII/1996.

Sementara itu, Malaysia adalah negara yang berpenduduk mayoritas beragama Islam sebesar $61,32 \%$. Walaupun persentase penduduk beragama Islam terhadap jumlah keseluruhan penduduknya tidak sebesar di Indonesia namun dalam menjalan tata pemerintahannya berdasarkan Syariat Islam. Karenanya pelaksanaan sertifikasi halal menjadi dilaksanakan di Malaysia melalui lembaga JAKIM (Jabatan Kemajuan Islam Malaysia), seperti halnya Badan penyelenggara Jaminan Produk Halal (BPJPH) di Indonesia menjadi penting karena menyangkut kebutuhan penduduk mayoritasnya.

Di era globalisasi, khususnya masyarakat yang tinggal di kawasan Asia Tenggara, persoalan halal dan haram di sebuah negara bukan hanya menjadi kepentingan warga negara bersangkutan, tetapi juga bagi warga negara asing. Sebabnya adalah semakin tipisnya batas antar negara dan semakin mudahnya orang asing masuk ke wilayah 


\section{PELITA}

negara lain. Maka tidak mengherankan jika sebuah negara dengan penduduk muslim sebagai minoritas, persoalan halal haram tetap diperhatikan.

Di wilayah Asia Tenggara, Indonesia dan Malaysia merupakan dua negara yang penduduknya mayoritas beragama Islam. Dengan demikian membandingkan pelaksanaan sertifikasi halal oleh kedua lembaga di dua negara yang bertetanggaan dengan karakter masyarakatnya yang relatif tidak berbeda menjadi menarik untuk bahan studi kajian. Untuk itulah, studi ini mengkaji tentang mekanisme pelaksanaan sertifikasi halal yang dilaksanakan oleh MUI di Indonesia dan oleh JAKIM di Malaysia, serta perbandingan mendasar antara pelaksanaan sertifikasi di kedua negara yang terkadang menjadi konflik ekonomi.

\section{Kerangka Konseptual}

Kesadaran menyertakan sertifikat halal pada produsen makanan/obatobatan/kosmetika lokal di Indonesia belum begitu tinggi. Bandingkan di banyak negara non muslim yang begitu bersemangat mendapatkan label halal pada produknya. Bukan karena ingin menerapkan syariah dalam hidupnya, melainkan untuk memenangkan persaingan di pasar umat islam. Apa lagi, sekarang sudah muncul kecenderungan di banyak kalangan non muslim yang menyukai produk yang bersertifikat halal, karena mereka percaya bahwa yang halal itu lebih terkontrol kualitasnya sehingga lebih bersih dan lebih sehat.

Hubungan agama dan negara di Indonesia dalam penanganan sertifikasi produk halal dapat dilacak dari ketentuan produk perundang-undangan. Di antaranya adalah Undang-Undang Nomor 7 Tahun 1996 tentang Pangan, Undang-undang Nomor Nomor 8 Tahun 1999 tentang Perlindungan Konsumen dan Peraturan Pemerintah Nomor 69 Tahun 1999 Tentang Label dan Iklan Pangan, serta yang terbaru Undang-undang Nomor 33 tahun 2014 tentang Jaminan Produk Halal.

Jika dicermati aturan yang ada dalam UU Undang-undang Nomor 7 Tahun 1996 tentang Pangan maupun Peraturan Pemerintah Nomor 69 Tahun 1999 Tentang Label dan Iklan Pangan di atas dapat ditarik kesimpulan sebagai berikut :

1. Ketentuan mengenai kehalalan sebuah produk cukup dengan keterangan bahwa produk tersebut halal. Keterangan itu dicantumkan sendiri oleh produsen. hal itu juga hanya bersifat fakultatif, bukan keharusan. 


\section{PELITA}

2. Tidak perlu ada lembaga khusus yang mensertifikasi produk halal. produsen sendiri yang mencantumkan keterangan halal itu pada produknya.

Selanjutnya UU No 33 tahun 2014 tentang Jaminan Produk Halal. Undangundang ini merupakan produk peraturan perundang-undangan yang paling kongrit dan komprehensif mengenai sertifikasi produk halal, karena memang merupakan UU khusus mengenai masalah tersebut. Keluarnya undang-undang ini dapat dikatakan sebagai era baru penanganan sertifikasi halal di Indonesia.

Beberapa ketentuan UU No. 33 tahun 2014 tentang Jaminan Produk Halal antara lain pasal 4 yang menyatakan bahwa Produk yang masuk, beredar dan diperdagangkan di Indonesia wajib bersertifikat halal. Selanjutnya Pasal 5 ayat mengamanatkan dibentuknya Badan penyelenggara Jaminan Produk Halal (BPJPH) yang menurut ayat (5) ketentuan mengenai fungsi, tugas, dan susunan organisasi BPJPH diatur dalam Peraturan Presiden.

Wewenang BPJPH antara lain merumuskan dan menetapkan kebijakan JPH,menetapkan norma, standard, prosedur dan kriteria JPH, menetapkan dan mencabutsertifikat halal pada produk luar negeri serta melakukan registrasi sertifikat halal padaproduk luar negeri. Namun walaupun sedah dibentuk BPJPH peran MUI masih cukup kuat.Ada tiga peran MUI terkait sertifikasi halal. Mulai dari penerbitan surat rekomendasi produk halal yang nantinya ditindaklanjuti BPJPH. Sebelum BPJPH mengeluarkan sertifikasi halal, harus ada keputusan MUI terkait dengan kehalalan produk tersebut.Peran kedua, MUI tetap memiliki wewenang untuk mengeluarkan fatwa halal terhadap produk yang didaftarkan di BPJPH. Selain itu, MUI memiliki peran tidak tergantikan untuk mengeluarkan sertifikasi terhadap Lembaga Pemeriksa Halal (LPH), yaitu organisasi auditor produk halal.

Karena itu di Indonesia, BPJPH yang bekerja sama dengan MUI akan memainkan peranannya untuk menerbitkan sertifikasi halal dan melakukan pengawasan produk di Indonesia. Dengan begitu, penegakan hukum terkait UU JPH menjadi lebih terjamin dari sebelumnya.Sementara itu, di Malaysia sendiri sejak awal JAKIM Jabatan Kemajuan Islam Malaysia) yang merupakan salah satu lembaga yang dibentuk langsung oleh Pemerintah Malaysia dan mekanisme kerja lembaga ini langsung di bawah pemerintah Malaysia. 


\section{PELITA}

\section{B. METODE PENELITIAN}

Kajian ini menggunakan studi pustaka sebagai bagian dari metode ilmiah untuk menjelaskan permasalahan dan pencapaian tujuan kajian. Metode ilmiah berlandaskan, terdiri atas tiga fase, yakni untuk mencari jawaban secara ilmiah, dasar metodologi untuk membuktikan jawaban tersebut, dan guna menginterpretasikanhasil penelitian (Hadi, Sutrisno, 1980).

Maksud studi Pustaka dalam penelitian kajian yang lebih bersifat akademik ini, untuk menyusun hipothesis (Long, Th, cs., 1985). Di samping itu, studi pustaka juga diperlukan oleh peneliti dalam upaya menemukan permasalahan penelitian yang tertera jelas di setiap historical background (Borg, Walter R., 1983). Bahkan jika kita teliti lebih cermat, theoritical framework dan arah perkembangan penelitian pendidikan mutakhir dapat kita gali dari studi pustaka (Ehrlich, Eugine amp Murphy,D., 1985). Lebih tandas, Edward S. Balian (1983), darimana materi kajian pustaka dapat diperoleh Serta seberapa jauh peranan pustaka dalam mengorganisasi suatu permasalahan penelitian.

Untuk menjelaskan mekanisme pelaksanaan sertifikasi produk halal yang dilaksanakan oleh dua negara, yaitu Indonesia dan Malaysia dipergunakan beberapa literatur baik berupa buku, website dan berita-berita terkait yang sudah dipublikasikan.

\section{HASIL DAN PEMBAHASAN}

\section{Mekanisme Sertifikasi Halal di Indonesia}

Penyelenggaraan pelaksanaan sertifikasi halal di Indonesia dilaksanakan oleh Badan penyelenggara Jaminan Produk Halal (BPJPH) yang bekerjasama dengan LPPOM MUI Adapun mekanisme alur penanganan sertifikat halal, menurut penjelasan di situs resmi LPPOM (Lembaga Pengkajian Pangan, Obat-obatan, dan Kosmetika)MUI dapat dideskripsikan dalam bentuk bagan yang disajikan dalam halaman berikut ini. 


\section{PELITA}

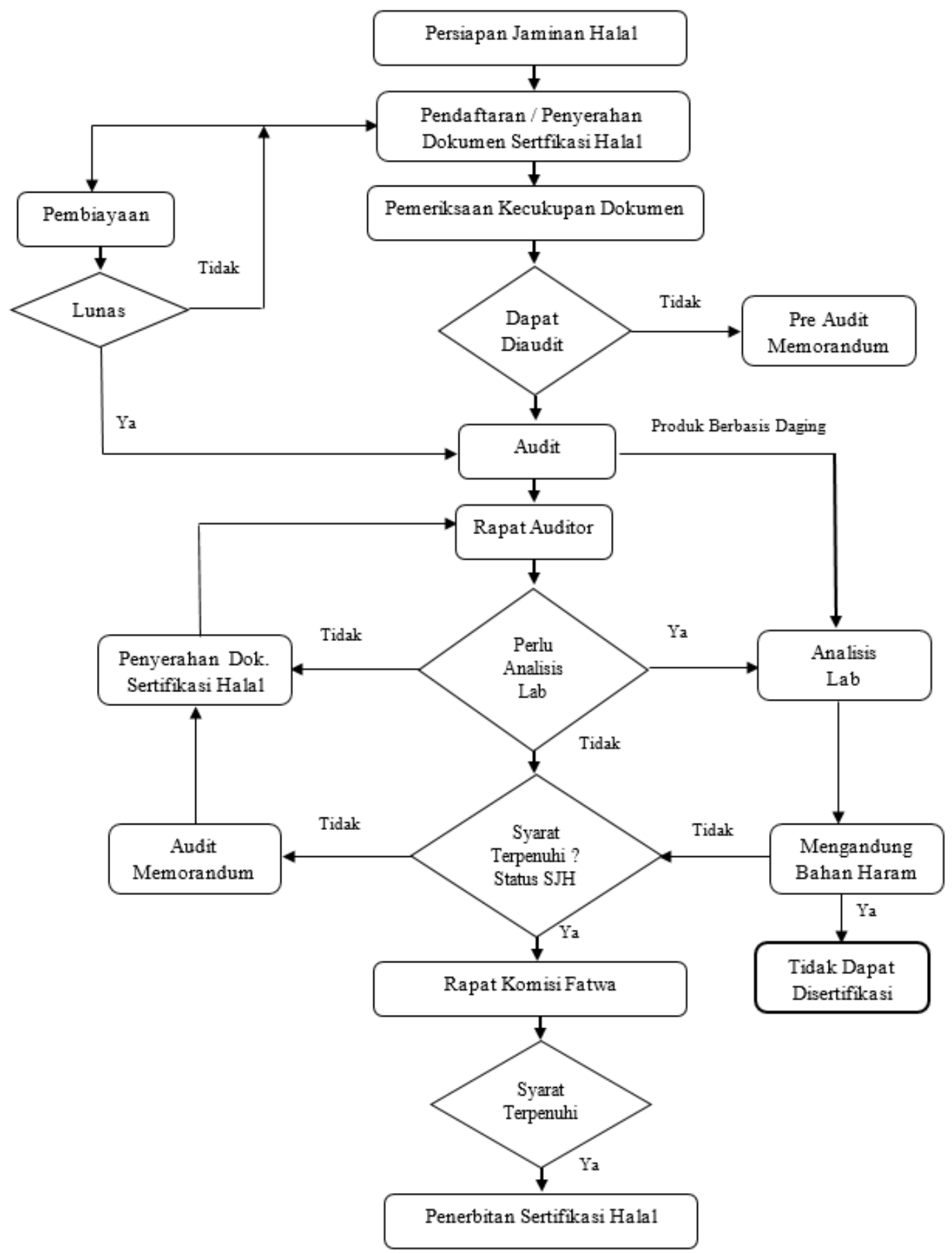

Sumber:http://www.halalmui.org/newMUI/index.php/main/go_to_section/39/1328/ page.

\section{Gambar 1}

\section{Diagram Alur Pengurusan Sertifikasi Halal}




\section{PELITA}

Di Indonesia sejak diterbitkannya UU No 33 tahun 2014 tentang Jaminan Produk Halal pada tahun 2017 telah dibentuk Badan penyelenggara Jaminan Produk Halal $(\mathrm{BPJPH})$ tapi tanpa mengesampingkan peran MUI. Karena hubungan diantara keduanya, terdapat keunikan tersendiri, yang menjelaskan antara hubungan negara dengan agama, sebagaimana berikut :

1. Negara Sebagai Lembaga yang Mengatur

Kehadiran UU No 33 tahun 2014 tentang Jaminan Produk Halal telah mengubah eksistensi sertifikat produk halal dari fakultatif menjadi imperatif, terutama produk dari luar. Dulu keterangan halal itu bahkan juga tidak bisa disebut fakultatif, karena sebenarnya negara sama sekali tidak memberi perintah maupun anjuran. Negara tidak memberi pilihan agar produsen atau pelaku usaha memberi keterangan halal atau boleh tidak memberi.

Keuntungan produsen dari pencantuman keterangan halal bisa jadi pada sisi marketingnya. Masyarakat Indonesia yang mayoritas muslim merupakan pasar yang jelas untuk memasarkan barang-barang halal. Bisa jadi tidak semua muslim Indonesia mempersoalkan masalah halal dan haram. Tingkat ketaatan seseorang sangat menentukan hal itu. Namun dipastikan ada muslim yang mempersoalkannya. Dengan pencantuman keterangan halal maka kebutuhan muslim yang taat terpenuhi, sedangkan mereka yang tidak taat juga tidak terganggu. Maka pencantuman keterangan halal lebih menguntungkan dari pada tidak.

Namun peneliti berpendapat lebih jauh bahwa fokus utama dalam pelaksanaan sertifikasi halal ini bukanlah pada persoalan halal atau haram, melainkan lebih pada penyampaian kebenaran infomasi agar masyarakat memiliki keamanan dan kepastian terhadap barang-barang yang dikonsumsi atau yang digunakan.

2. Gerakan Masyarakat (Civil Society)

Pada awalnya di Indonesia, persoalan pernyataan tentang produk yang halal merupakan persoalan sensitif bagi umat Islam, sementara negara kurang respon, munculnya gerakan civil society yang dimotori oleh MUI melalui LPPOMnya.

Lembaga yang memiliki tanggung jawab melindungi umat Islam ini berinisiatif untuk memberi sertifikat halal terhadap produk. Ketidakhadiran negara dalam menentukan sertifikasi halal, selain bisa dibaca bahwa negara kurang respon 


\section{PELITA}

sebagaimana telah diuraikan di atas, juga bisa dimaknai bahwanegara membuka pelung bagi gerakan civil society.

Menurut Azra (2000:8) civil society yang disebutnya masyarakat madani memang merupakan entitas yang berbeda dengan negara. Namun keduanya tidak dalam posisi berhadap-hadapan, sebaliknya terjalin hubungan yang lebih kooperatif Berdasarkan pandangan ini negara dan civil society bekerja sama, saling mengisi dan membantu. Kehadiran MUI dengan LPPOMnya merupakan upaya memenuhi kebutuhan masyarakat. Menurut Hikam ciri utama civil society adalah keswasembadaan dan kesukarelaan sehingga mampu melakukan kiprahnya sendiri secara swasembada.

Pembentukan LPPOM MUI didasarkan atas mandat dari Pemerintah agar Majelis Ulama Indonesia (MUI) berperan aktif dalam meredakan kasus lemak babi di Indonesia pada tahun 1988. LPPOM MUI didirikan pada tanggal 6 Januari 1989 untuk melakukan pemeriksaan dan sertifikasi halal.

Berdasarkan Keputusan Menteri Agama Nomor 518 Tahun 2001 Tentang Pedoman dan Tata Cara Pemeriksaan dan Penetapan Pangan Halal Pasal 1 huruf d, sertifikat halal dikeluarkan oleh lembaga pemeriksa. Pemerintah tidak menentukan siapa yang dimaksud dengan lembaga pemeriksa, melainkan hanya menetapkan kriterianya.

3. Simbiosis Mutualisme

Pasca terbitnya UU No 33 tahun 2014 tentang Jaminan Produk Halal pada tahun 2017 telah dibentuk Badan penyelenggara Jaminan Produk Halal (BPJPH) tidak serta merta meniadakan peran dari LPPOM MUI. Hal ini seperti dikatakan oleh Menteri Agama Lukman Hakim Saifuddin dalam Harian Merdeka.com (11 Oktober 2017) : “Ada tiga kewenangan MUI meski sudah ada BPJPH. Mulai dari penerbitan surat rekomendasi produk halal yang nantinya ditindaklanjuti BPJPH. Sebelum BPJPH mengeluarkan sertifikasi halal, harus ada keputusan MUI terkait dengan kehalalan produk tersebut. Peran kedua, MUI tetap memiliki wewenang untuk mengeluarkan fatwa halal terhadap produk yang didaftarkan di BPJPH. Selain itu, MUI memiliki peran tidak tergantikan untuk mengeluarkan sertifikasi terhadap Lembaga Pemeriksa Halal (LPH), yaitu organisasi auditor produk halal. Auditor-auditor yang terkait ini harus mendapat persetujuan dari MUI". 


\section{PELITA}

Menteri Agama Lukman Hakim Saifuddin menyampaikan bahwa "BPJPH yang bekerja sama dengan MUI akan memainkan peranannya untuk menerbitkan sertifikasi halal dan melakukan pengawasan produk di Indonesia. Dengan begitu, penegakan hukum terkait UU JPH menjadi lebih terjamin dari sebelumnya".

Secara tersendiri terdapat konfirmasi oleh Sukoso selaku Kepala BPJPH yang menjelaskan bahwa "Badan yang dipimpinnya itu bersinergi dengan MUI untuk tata kelola yang baik terkait UU JPH. Dengan kerjasama yang baik itu akan menjadi alat penting untuk akses pasar dan meningkatkan daya saing produk lewat sertifikasi produk. Kerja sama yang baik untuk pelayanan JPH dengan transparansi standar halal ini, dengan komunikasi yang baik menjadikan JPH memberi nilai tambah terciptanya daya saing produk."

Kewenangan BPJPH lainnya adalah melaksanakan meregistrasi produk halal di dalam dan luar negeri, mencabut label halal, memeriksa akreditasi LPH dan mengupayakan penegakkan hukum apabila ditemukan pelanggaran terkait produk halal.

Adanya kerjasama antara BPJPH dengan LPPOM di Indonesia dalam pelaksanaan sertifikasi halal terhadap produk yang dipasarkan, walaupun mekanismenya relatif lebih panjang karena melibatkan dua buah lembaga, namun memiliki tingkat kepastian yang memadai, mengingat produk dari setiap produsen akan melalui proses uji labaratorium.

Di Negara Indonesia produsen atau pemilik usaha yang sudah mendapatkan sertifikasi halal akan berhak untuk label halal pada produknya. Label adalah merupakan bagian dari system pengawasan mutu atas suatu produk dan menurut ketentuan hukum yang berlaku diisyaratkan bahwa terhadap produk makanan (food) halal yang dinyatakan dapat dikonsumsi oleh masyarakat Muslim harus ditandai dengan label halal.

Pengertian label halal di sini merupakan sebuah penanda bahwa produk tersebut baik sebelum maupun sesudahnya telah melalui proses manajemen produksi secara halal, termasuk di dalamnya memiliki kandungan bahan baku serta muatan isi produknya adalah benar-benar halal sesuai dengan aturan hukum yang berlaku. Penentuan yang dimaksud maksud dengan produk makanan halal adalah produk makanan yang tidak mengandung atau bahan yang haram atau dilarang dikonsumsi 


\section{PELITA}

oleh umat Muslim, baik yang menyangkut bahan baku makanan, bahan tambahan makanan, bahan bantu dan bahan penolong lainnya termasuk bahan makanan yang diolah melalui proses rekayasa genetika dan iradiasi makanan, serta pengelolaannya dilakukan sesuai dengan ketentuan hukum Agama Islam.

Sementara itu, di dalam Peraturan Pemerintam Nomor 69 Tahun 1999 tentang Label dan Iklan Pangan pasal 1 angka 5, dijelaskan bahwa aturan tentang label Halal menurut hukum adalah suatu tanda yang disebut sebagai Label Halal merupakan keterangan jaminan mutu, berlaku sebagai bahan informasi kepada masyarakat yang juga menjelaskan bahwa produk tersebut adalah halal untuk dikonsumsi oleh umat Muslim.

\section{Mekanisme Sertifikasi Halal di Malaysia}

Jabatan Kemajuan Islam Malaysia (JAKIM) diputuskan menjadi lembaga halal satu-satunya di Malaysia. Hal ini dilakukan demi mengefektifkan standard halal dan mencegah kebingungan diantara kaum muslimin pada logo halal. Tujuan Pemerintah Malaysia memberlakukan ketentuan ini untuk menghindari berbagai perangkap yang terjadi sebelumnya, dimana sertifikat halal telah dikeluarkan oleh 7 lembaga pemberi sertifikasi halal sebelumnya, dan beberapa diantara mereka tidak bertanggung jawab.

Untuk melaksanakan sertifikasi dan label halal JAKIM di Malaysia sudah memiliki buku Manual Prosedur Pensijilan dan Halal Malaysia (SEMAKAN KETIGA). Buku manual ini menjadi pedoman bagi para pelaku usaha di Negara Malaysia dalam mendapatkan sertifikasi dan label halal.

Pada dasarnya peran JAKIM dan BPJPH tidak secara signifikan berbeda. Di Malaysia pemilik usaha mengajukan sertifikasi halal lewat sistem e-Halal. Pemilik usaha harus melaporkan seluruh bahan yang digunakan, siapa pemasok bahan tersebut, dan apakah si pemasok sudah memperoleh sertifikat halal. Jika keraguan dalam bahannya yang digunakan, JAKIM akan mengambil sampel dan mengirimkannya ke Departemen Kimia untuk diaudit. Selain itu, audit juga dilaksanakan di pabrik pengolahan untuk memastikan aspek halal dipatuhi. Bahan akan dicek apakah sudah dilaporkan, di antaranya melalui faktur pembelian. Proses produksi juga ditekankan, termasuk alur pengolahan, peralatan, serta kebersihan lingkungan dan pekerja. 


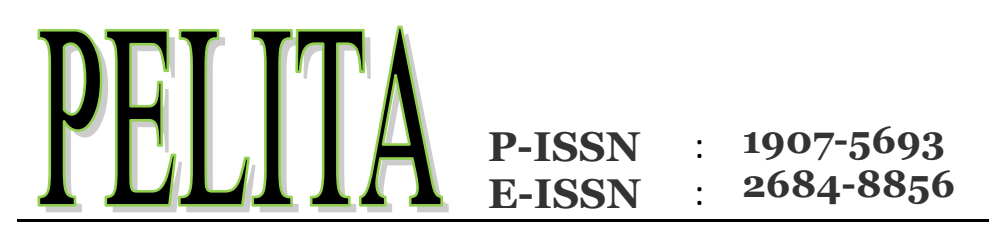

JAKIM telah mewajibkan perusahaan multinasional menerapkan sistem jaminan halal atau menunjuk auditor internal untuk mengawasi proses produksi. Auditor harus memastikan prosesnya sesuai dengan persyaratan halal.

Proses uji laboratorium yang diterima oleh JAKIM harus didasarkan pada hasil uji laboratorium yang dilaksanakan oleh lembaga laboratorium yang memiliki akreditasi, sehingga sebelum ke JAKIM pemilik usaha harus terlebih dulu menguji produknya di laboratorium yang terakreditasi.

Setelah sertifikat halal keluar, inspeksi mendadak (sidak) dilakukan di pabrik minimal setahun sekali. Untuk perusahaan di sektor tinggi risiko seperti produk berbahan daging, lemak, dan rumah potong hewan serta perusahaan tanpa sistem jaminan halal atau auditor internal, sidak akan dilaksanakan beberapa kali setahun.

Jika ada keluhan dari masyarakat, JAKIM bersama lembaga berwenang seperti Kementerian Perdagangan Dalam Negeri, Koperasi, dan Konsumerisme, Kementerian Kesehatan, Departemen Kesehatan Hewan, Bea Cukai, dan badan setempat akan menggelar sidak.

\section{KESIMPULAN DAN REKOMENDASI}

Mekanisme pelaksanaan sertifikasi halal diantara Indonesia dan Malaysia memiliki kemiripan, walaupun terdapat pula perbedaannya.

1. Di Indonesia mekanisme pelaksanaan sertifikasi halal semula dilaksanakan oleh LPPOM MUI, namun kemudian Pemerintah Indonesia membentuk Badan penyelenggara Jaminan Produk Halal (BPJPH), walaupun pada pelaksanaannya kedua lembaga ini melakukan kerjasama. Pelaku usaha akan menguji sampel produknya pada LPPOM MUI dan hasilnya akan direkomendasikan ke BPJPH.

2. Di Malaysia mekanisme pelaksanaan sertifikasi halal semula dilaksanakan oleh lembaga Independen, namun kemudia Pemerintah Malaysia membentuk JAKIM (Jabatan Kemajuan Islam Malaysia). JAKIM ini akan menerima hasil rekomendasi dari Laboratorium terakreditasi dari produk yang diajukan oleh pemilik usaha.

Baik BPJPH di Indonesia maupun JAKIM di Malaysia kedua lembaga ini juga menerima kerjasama pemberian sertifikat terhadap produk-produk dari negara lain, walaupun pernah terjadi perbedaan paham diantara dua lembaga pemberi sertifikasi 


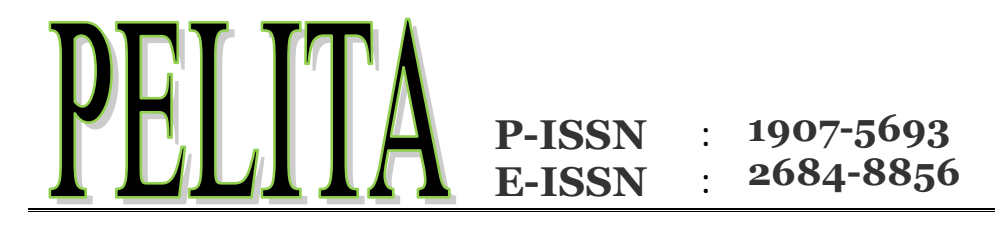

halal ini, yakni pada tahun 2017 dimana Pemerintah Indonesia menolak produk impor ke Indonesia yang memakai sertifikasi halal dari JAKIM, pasca adanya kasus pada produk Cadbury.

\section{E. REFERENSI}

Alie, I. M. (Penyunting). (2003). Bunga Rampai jaminan Produk Halal Di Negara Anggota Mabim. Jakarta: Dirjen Bimas islam dan Penyelenggaraan Haji Depag RI.

Bisri, H. (1995). 20 Tahun Majelis Ulama Indonesia. Jakarta : MUI.

Keputusan Presiden Nomor 23 Tahun 1991 tentang Kesehatan.

Moleong, J. L. (2009). Metode Penelitian Kualitatif. Cetakan ke-26. Bandung : Remaja Rosda Karya.

Mudzhar, M. A. (1998). Fatwa-Fatwa Majelis Ulama Indonesia : Sebuah Studi Hukum Islam di Indonesia 1975-1988.

Peraturan Pemerintam Nomor 69 Tahun 1999 tentang Label dan Iklan Pangan.

Sakr, A. H. (1996). Understanding Halal Foods, Fallacies and Facts. Illinois: Foundation For Islamic Knowledge.

Undang-Undang Nomor 23 Tahun 1992 tentang Kesehatan

Undang-Undang Nomor Nomor 7 Tahun 1996 tentang Pangan.

Undang-Undang Nomor 33 Tahun 2014 tentang Jaminan Produk Halal.

Wahyuni, E. S. 2003. Aspek Hukum Sertifikasi dan Keterkaitannya dengan Perlindungan Konsumen. Bandung : PT. Citra Aditya Bakti. 